CUADERNOS DE ESTUDIOS GALLEGOS, LXVI Núm. 132 (enero-diciembre 2019), págs. 343-372

ISSN: $0210-847 \mathrm{X}$

https://doi.org/10.3989/ceg.2019.132.11

\title{
BARTOLOMÉ CALDERÓN E A GALICIA QUE NUNCA EXISTÍU*
}

\author{
Miguel CABo \\ Universidade de Santiago de Compostela \\ ORCID iD: https://orcid.org/0000-0002-8099-3895
}

* HISTAGRA ED431C 2017111. GRC-Galicia. Este traballo inscríbese dentro do proxecto Los
vectores del cambio estructural de las agriculturas atlánticas ibéricas: moto-mecanización y espe-
cialización lechera, referencia: HAR2016-77441-P (IP: Lourenzo Fernández Prieto,). Agradezo a
Lourenzo Fernández e a Diego Conde as súas suxerencias a partir dunha versión inicial deste texto,
así como as recibidas durante o proceso de avaliación.

Copyright: @ 2019 CSIC. La edición electrónica de esta revista se distribuye bajo los términos de una licencia de uso y distribución Creative Commons Reconocimiento 4.0 Internacional (CC BY 4.0).

Cómo citar/Citation: Miguel CABO, "Bartolomé Calderón e a Galicia que nunca existíu", Cuadernos de Estudios Gallegos, 66, núm. 132 (2019), págs. 347-376, https://doi.org/10.3989/ ceg.2019.132.11 


\title{
BARTOLOMÉ CALDERÓN E A GALICIA QUE NUNCA EXISTÍU
}

\begin{abstract}
RESUMO:
Bartolomé Calderón (1861-1931) foi un moi influínte xornalista galego especializado en cuestións económicas, en especial agrarias. Cría que Galicia estaba chamada a seguir unha vía de desenvolvemento semellante á de Dinamarca, sobre os piares da especialización láctea e o cooperativismo e centrada nas exportacións ós mercados europeos. Mantiña posicións moi críticas cara ó Estado español debido ó seu centralismo e proteccionismo deseñados para protexer os intereses dos produtores de cereal das rexións centrais e meridionais, chocando daquela co desenvolvemento que el promovía para os sistema agrario galego. As ideas de Calderón foron moi populares entre os líderes agraristas e os galeguistas durante as dúas primeiras décadas do século XX pero a súa influencia decaeu posteriormente e caeu no esquecemento despois da súa morte en Francia, onde residía dende había máis de corenta anos, en 1931.

PALABRAS CLAVE: agrarismo, nacionalismo, cambio técnico, política económica, librecambio.
\end{abstract}

\section{BARTOLOMÉ CALDERÓN Y LA GALICIA QUE NUNCA EXISTIÓ}

\section{RESUMEN:}

Bartolomé Calderón (1861-1931) fue un muy influyente periodista gallego especializado en cuestiones económicas, en especial agrarias. Creía que Galicia estaba llamada a seguir una vía de desarrollo semejante a la de Dinamarca, sobre los pilares de la especialización láctea y el cooperativismo y centrada en las exportaciones a los mercados europeos. Mantenía posiciones muy críticas hacia el Estado español debido a su centralismo y proteccionismo diseñados para proteger los intereses de los productores de cereal de las regiones centrales y meridionales, chocando pues con el desarrollo que él promovía para el sistema agrario gallego. Las ideas de Calderón fueron muy populares entre los líderes agraristas y galeguistas durante las dos primeras décadas del siglo XX pero su influencia decayó posteriormente y cayó en el olvido tras su muerte en Francia, donde residía desde hacía más de cuarenta años, en 1931.

PALABRAS ClAVE: agrarismo, nacionalismo, cambio técnico, política económica, librecambio.

\section{BARTOLOMÉ CALDERÓN AND THE GALICIA THAT NEVER WAS}

\begin{abstract}
:
Bartolomé Calderón (1861-1931) was a highly influential Galician journalist specialized in economic issues, particulary agrarian ones. He thought Galicia was to follow a development path similar to Denmark, with dairy specialization and cooperatism as pillars and focused on exports to the European markets. He was very critical with the Spanish state because of its centralism and protectionism in order to protect the interests of grain-producers in the Center and South, thus colliding with the development route he promoted for the Galician agrarian system. Calderón's ideas were very popular among agrarian and galicianist leaders during the 1900s and 1910s but his influence slowly declined afterwards and fell into oblivion after his death in France, where he lived for more than forty years, in 1931.

KEY WORDS: agrarian movement, nationalism, technical change, economic policy, free-trade.
\end{abstract}


Recibido/Received: 04/06/2018

Aceptado/Accepted: 31/01/2019

$\mathrm{B}$ artolomé Calderón Neira (1861-1931) ${ }^{1}$ foi un analista da economía galega de traxectoria atípica e estilo heterodoxo que exerceu unha influencia máis que considerable a través dunha notable actividade xornalística e da incorporación de moitas das súas propostas por parte do movemento agrarista e do nacionalismo. Malia todo, a súa figura caeu no esquecemento e son moi escasas as referencias á súa figura na historiografía e moi extensas as lagoas sobre a súa biografía. As causas son múltiples, comezando polo feito de residir en Francia a meirande parte da súa vida e a súa repulsa a calquera tipo de notoriedade ou recoñecemento, o que explica que escribise moitos dos seus artigos baixo pseudónimo ou que non exista nin un só retrato $\mathrm{seu}^{2}$. Outro motivo é que Calderón sempre fixo gala dunha feroz independencia e nunca se deixou encaixar nunha etiqueta política ou partidista, de xeito que non foi reivindicado por ningunha formación e tampouco polo nacionalismo galego, que pola súa capacidade para moldear a memoria colectiva na nosa terra remata en moitos casos por decidir a inclusión ou non no canon patriótico dos homes e mulleres do pasado. Podemos simbolizalo no feito de Calderón non aparecer mencionado no Sempre en Galiza, verdadeira vulgata da doutrina nacionalista.

Non resulta un artificio retórico afirmar que Bartolomé Calderón é practicamente un descoñecido, dende logo para o público en xeral pero tamén para moitos especialistas. O pioneiro en ocuparse da súa figura foi José Antonio Durán, que o incluíu no que denominou "xeración antre dous séculos" e chamou a atención sobre as súas aportacións en La Voz de Galicia e na revista Prácticas Modernas (1903-1913) $)^{3}$. Sen embargo nunca se decidiu a adicarlle unha monografía nin unha escolma como fixo con Valeriano Villanueva (1865-1943), tan vencellado

\footnotetext{
1 Abreviaturas empregadas: ANT: A Nosa Terra; CT: La Crónica del Trabajo (Santiago); IF: Irmandades da Fala; PAP: El Progreso Agrícola y Pecuario (Madrid); PM: Prácticas Modernas (A Coruña); VG: La Voz de Galicia (A Coruña).

2 Federico Maciñeira menciona a anécdota de que unha revista lle pedíu que mediase para que Calderón lles enviase un retrato e que se negou, argumentando que o importante eran as ideas e non a súa persoa; "In memoriam. En la muerte de Bartolomé Calderón", La Voz de Galicia (10-12-1931).

3 José Antonio Durán, Agrarismo y movilización campesina en el país gallego (1875-1912), Madrid, Siglo XXI, 1977, páxs. 119-139.
} 
a Calderón ${ }^{4}$. Posteriormente outros autores téñense ocupado tanxencialmente de Calderón, como Lourenzo Fernández Prieto no seu estudo pioneiro sobre o cambio técnico no primeiro terzo do século XX ou deste autor e Cabo que o encadran como unha das figuras do rexionalismo agrícola que en Galicia recollería moitas das inquedanzas (pero poucas das propostas) do Regeneracionismo, ou Diego Conde nos seus estudos sobre a veterinaria e a gandería en Galicia e sobre outro personaxe cuxa traxectoria se cruza en varias ocasións coa de Calderón, o veterinario Juan Rof Codina (1874-1967) . Pouca bagaxe para un autor cunha obra máis que salientable.

Esta investigación proponse rescatar do esquecemento a un personaxe dificilmente etiquetable e trazar unha presentación coherente do seu pensamento social, económico e político, disperso en varios libros, aportacións a congresos e sobre todo centos de artigos na prensa xeral e agraria.

\section{BARTOLOMÉ CALDERÓN: BIOGRAFÍA INCOMPLETA}

Neste artigo preséntanse datos novidosos sobre a súa vida persoal, que Calderón sempre tentou agochar detrás do seu inesgotable labor publicístico. Moito permanece aínda na escuridade, posto que sen dispor de correspondencia nin arquivo privado resulta complicado reconstruír o marco intelectual no que se moveu ou os motivos últimos de determinadas decisións e posicionamentos.

Bartolomé Calderón nace en Muros o 14 de agosto de 1861 e é bautizado tres días despois. Seu pai era Juan Antonio Calderón Caamaño, avogado e rexistrador de hipotecas e súa nai Genovena Neira, de Fisterra. ${ }^{6}$ Juan Antonio Calderón nacera en 1832 na parroquia sonense de San Vicente de Noal, no seo dunha familia influínte posto que seu avó José María Calderón y Arredondo fora rexidor perpetuo de Muros. Juan Antonio Calderón estuda Dereito en Santiago e posteriormente instálase na Coruña, onde se integrará nas filas canovistas e será avogado da Hermandad de la Paz y la Misericordia e decano do colexio de avogados entre 1894 e $1898^{7}$. O sustrato familiar semellaba predispoñer a Bartolomé ós estudos

\footnotetext{
4 Valeriano Villanueva, Organización del cultivo y de la sociedad agraria en Galicia y en la España atlántica (edición de J. A. Durán), Madrid, Xunta de Galicia e MAPA, 1984.

5 Lourenzo Fernández Prieto, Labregos con ciencia, Vigo, Xerais, 1992; Lourenzo Fernández PrieTO e Miguel CABO, "Agrarismo y regeneracionismo en la Galicia de comienzos del siglo XX. El discurso del regionalismo agrícola", Agricultura y Sociedad, 86 (1998), páxs. 133-162; Diego Conde Gómez, Canto val unha vaca? Da cuestión agraria á cuestión pecuaria en Galicia, Deputación da Coruña, 2014; Juan Rof Codina: renovación na veterinaria e gandería galega contemporánea, Vigo, Xerais, 2015.

6 Para a pescuda sobre o xenealoxía de Calderón contei coa valiosísima axuda de Pilar Rodríguez Suárez, Pirusa.

7 Juan A. Calderón, Discurso que en la solemne colación de grados de Licenciado en la Facultad de Jurisprudencia, celebrada el 27 de junio de 1852, pronunció Juan A. Calderón, Santiago, Universidad Literaria, 1852; Rosa María SAurín De LA IGLesia, Antonio, Francisco y Benigno de la Iglesia: una bio-
} 
universitarios e á inserción nas elites da sociedade da época, como un dos seus irmáns, Manuel Calderon Neira, que tras licenciarse en Dereito en Santiago en 1879 foi avogado e rexistrador en Ferrol e publicou varios libros, entre eles un de 1885 titulado Estudios hipotecarios y cuestión agraria que indica que compartía algúns dos intereses do seu irmán menor ${ }^{8}$.

E sen embargo por motivos que se descoñecen Bartolomé non segue o camiño que sería previsible dados os seus antecedentes familiares e nalgún momento na segunda metade dos anos oitenta emigra a Francia. Antes pasou por Madrid, posto que nunha rara concesión ás confidencias confesa nun artigo que vivíu algún tempo nesa cidade, que compara desfavorablemente con París (da que sería "ruín imitación"). Tería sido "baixo o califato de Romero Robledo", que foi ministro de Gobernación e gran muñidor electoral case ininterrompidamente entre 1874 e 1881 e logo en $1884-85^{9}$.

As primeiras colaboracións en prensa das que temos constancia apareceron en La Unión Nacional, diario pontevedrés que entre abril de 1900 e febreiro de 1901 defendeu as teses da efémera organización que baixo inspiración costista tentou canalizar os impulsos rexeneracionistas. Este xornal estaba controlado por republicanos locais e prestaba unha atención particular ás sociedades agrarias da bisbarra. Nel publícanse con periodicidade aproximadamente semanal artigos asinados por "Un gallego, París" que non ofrecen dúbidas sobre a súa autoría ${ }^{10}$. Os temas adiantan xa as constantes das seguintes tres décadas: comentarios sobre os concursos de gando, críticas ás elites políticas e sociais españolas polo seu desinterese polas actividades produtivas, a súa teima contra as touradas ou a confianza nas posibilidades económicas de Galicia. Trataríase pois dun autor que entra na escena de xeito tardío, posto que non temos localizada ningunha publicación en Francia nin en España previa a 1900 e na mencionada nota necrolóxica Federico Maciñeira afirma que efectivamente fora a súa colaboración en Unión Nacional o seu bautismo xornalístico.

Nestes primeiros artigos Calderón amosa xa un dominio indiscutible dos temas económicos, en particular todo o relacionado coa gandería, e ó tanto de todo o que se publicaba en linguas francesa e inglesa. Aínda que ó longo deste artigo se

\footnotetext{
grafia intelectual, Santiago, Instituto de Estudios Gallegos Padre Sarmiento - CSIC, 2003 (Anejos de Cuadernos de Estudios Gallegos, 31), páx. 190.

8 Unha das súas irmás, Rosa, sería na Segunda República secretaria do comité local de Muros da Unión Regional de Derechas (a CEDA); El Compostelano (20-11-1934).

9 "Madrí xusgado por un galego culto que vive e traballa en París", Rexurdimento (xaneiro de 1923).

${ }^{10}$ Federico Maciñeira con motivo do seu pasamento lembra que estaba perfectamente ó tanto da economía galega malia "cuarenta y tantos años de ausencia del terruño natal" e tamén confirma que "al calor de aquel famoso movimiento de la Unión Nacional inició, desde la capital francesa, su actuación en la prensa regional, defendiendo con calor y con gran sentido práctico los maltrechos intereses del agro y de la pesca"; MACIÑEIRA, "In memoriam...", op.cit.
} 
fará referencia principalmente ós artigos nos que expón as súas teses sobre economía, hai que ter en conta que polo menos a metade da súa produción son textos de natureza técnica sobre animais domésticos e cultivos ¿De onde proceden estes coñecementos? Na Universidade de Santiago consta que non cursou estudos, nin ata onde puidemos comprobar tampouco en ningunha facultade ou escola madrileña, dende logo non nas de Agronomía e Veterinaria. Tampouco no Instituto Agronómico francés de Grignon ${ }^{11}$. Puido facelo nalgunha universidade gala pero as pesquisas que fixemos nese sentido deron resultado negativo e na Académie d'Agriculture de France non consta ningún documento que mencione a Calderón nin ningunha publicación súa, igual que non ten ningún rexistro na Biblioteca Nacional de París. Valeriano Villanueva no seu obituario afirma que seguíu os cursos de agronomía de Louis Grandeau (1834-1911), cunha fórmula que incita a pensar que non o fixo de xeito regrado nin coa consecución dun diploma oficial ${ }^{12}$. Calderón fará referencia nalgunha ocasión á independencia que lle posibilitaba a súa situación, en contraste coa meirande parte dos analistas das cuestións agrarias que soían ser persoas vencelladas á Administración dun xeito ou outro (enxeñeiros como o director da Granxa agrícola coruñesa Leopoldo Hernández Robredo, veterinarios como Juan Rof Codina que era Inspector Provincial de Hixiene Pecuaria ou doutro xeito como Valeriano Villanueva que era fiscal no Corpo Xurídico Militar): "Los que nos ocupamos de fomento agrícola sin título, autorización ni representación agrícola de ninguna clase, sin más recomendación ni garantía que el valor y el alcance de nuestro propio trabajo..."13. Polo tanto todo indica que se trata dun autodidacta, e as sospeitas víronse confirmadas cun documento que permite asomarse á vida persoal de Calderón.

O catro de decembro de 1907 no concello de Sannois, ó Noroeste de París, o alcalde levanta acta do falecemento dun neno morto no parto fillo de Bartolomé Calderón, 46 anos, "debuxante", e a súa muller, a "empregada" de 28 anos Camille Henriette Buisson. ${ }^{14}$ Polo tanto era esa a profesión principal de Calderón, que efectivamente ilustraba el mesmo os seus artigos e libros con gran pericia. Nalgunha noticia de prensa menciónase que tamén era axente de bolsa pero é posible que se tratase dunha actividade complementaria ou ocasional ${ }^{15}$. Por referencias de prensa coñécese tamén que posuía un galiñeiro de grandes dimensións pero

\footnotetext{
11 Agradezo este dato a Juan Pan Montojo.

12 Valeriano Villanueva, "Una gran figura regional", La Voz de Galicia (09-01-1932), onde sinala que foi un dos introdutores en España do mendelismo, sobre o que efectivamente publica artigos no PAP e PM en 1912-13, data moi temperá segundo se deduce de Susana PINAR, "La introducción de la genética en España durante el primer tercio del siglo XX”, Llull, 22 (1999), páxs. 453-473.

13 PAP (7-01-1914).

${ }^{14}$ Copia escaneada do certificado de defunción facilitada amablemente pola arquiveira Chantal Fernández, Départment Population, Sannois.

15 "Falleció el ilustre escritor Bartolomé Calderón", VG (5-12-1931).
} 
non se pode saber ata qué punto era unha actividade profesional, aínda que asinará unha folla divulgativa en 1921 sobre o tema como "avicultor y publicista agrícola". Así mesmo, na correspondencia xerada pola Gran Guerra é mencionado en numerosas cartas, que aluden a xestións súas a favor de soldados e refuxiados, o que indicaría unha intensa involucración na sociedade local ${ }^{16}$.

En 1900 obtén o cuarto premio no Certamen Cientifico Mercantil na Coruña pero non vai recollelo persoalmente ${ }^{17}$. De feito é posible que visitase algunha vez que outra Galicia dende o seu exilio parisino pero non temos constancia de que o fixese. Ese mesmo ano comeza a súa colaboración con La Voz de Galicia, que se vai prolongar durante tres décadas ${ }^{18}$. Entre xuño de 1901 e febreiro de 1903 convírtese nun dos principais animadores da revista mensual editada en Santiago La Crónica del Trabajo. A experiencia é efémera pero adianta varios dos temas da que será a súa continuadora: a coruñesa Prácticas Modernas, dirixida polo avogado e concelleiro conservador (pero con sólidos vencellos con sociedades agrarias de distinto signo) José Gradaille Chao, que coñecera a Calderón en París en $1900^{19}$.

Prácticas Modernas vai prolongar a súa andaina durante dez anos (1903-1912) con periodicidade quincenal e acadará unha influencia maior ca ningunha outra revista do seu xénero, confirmada pola reprodución de moitos dos seus textos na prensa agrarista e unha cifra de 1.100 suscriptores (moitos deles colectivos) na altura de 1907. Boa parte do éxito radicaba no seu estilo claro e ameno, sen academicismos, e con artigos orixinais e concebidos para as condicións existentes en Galicia, non meras traducións de textos estranxeiros como sucedía en tantos casos, agás algúns reproducidos de revistas francesas. Bartolomé Calderón, Valeriano Villanueva e o rexionalista Amador Montenegro Saavedra serán os seus principais sostedores pero nela colaborarán tamén técnicos dos servizos oficiais e outras figuras do rexionalismo como Rodrigo Sanz, Aurelio Ribalta ou o mesmo Manuel Murguía. Calderón publicaba como mínimo un artigo por número, pero bastantes dos editoriais levan o selo do seu estilo e ademais asinaba con pseudónimo outras moitas colaboracións, en concreto como Agro as relacionadas con forraxes e prados, G. Bankiva sobre avicultura e cunicultura e Alocitro sobre

\footnotetext{
${ }_{16}$ Información amablemente facilitada por Jean-Marc Delaplace, responsable da web Sannois d'hier à aujourd'hui.

17 El Noroeste (31-10-1900).

18 Salvo erro ou omisión o seu primeiro artigo aparece o 20 de marzo de 1900, anónimo pero asinado dende París e que presenta un dos seus temas máis característicos: a crítica contra as touradas, posto que no Folies Bergère se prepara un espectáculo taurino e o xornalista di que desprestixian a España e que caen "del otro lado de la civilización”. Para unha contextualización, José Antonio Durán, "La cuestión agraria en La Voz”, La Voz de Galicia (17-11-1982).

19 A única colección completa que saibamos é a da Escola Municipal de Artes e Oficios de Vigo. O derradeiro disponible é o 230, correspondente a decembro de 1912. Algúns datos sobre a biografía de Gradaille en España (La Habana), 7 (25-06-1922).
} 
floricultura e horticultura, ademais da meirande parte das ilustracións ${ }^{20}$. En xuño de 1912 deixa de colaborar coa mesma, sen que se aclaren os motivos ${ }^{21}$. Haxa ou non relación causa-efecto, o feito é que Prácticas Modernas pasa a ser mensual e medio ano despois desaparece, aínda que seguirá aparecendo unha sección con ese nome adicada a Galicia, Asturias e Cantabria na barcelonesa El Cultivador Moderno (onde tamén publicará Calderón).

Pódese considerar que os anos dez constitúen o cumio da influencia de Calderón, posto que inspira a organización de concursos de gando na provincia, elabora boa parte dos cuestionarios ó redor do que se articulan as Asembleas Agrarias, os seus puntos de vista son recollidos con frecuencia na prensa agrarista e a través do agrarismo inflúe no programa das Irmandades da Fala en puntos esenciais (cooperativismo, orientación gandeira, librecambismo...). Tamén son os anos nos que publica os seus libros El pan y el trigo en el problema de las subsistencias y de la economía nacional (el pan barato y los toros caros) ${ }^{22} \mathrm{e}$ Fomento de la ganadería ${ }^{23}$ e nos que a súa firma aparece en numerosas publicacións galegas, españolas e da emigración.

Durante a Primeira Guerra Mundial as súas crónicas dende París en $\mathrm{La} \mathrm{Voz}$ de Galicia cobran un interese suplementario, posto que a maiores dos temas económicos habituais reflexiona sobre as consecuencias do conflito, no que adopta como era previsible unha postura decididamente aliadófila ${ }^{24}$. Tamén dende o punto de vista agrario fai unha lectura moi interesante, pronosticando por exemplo que a guerra duraría como mínimo un ano e que Alemania polo seu perfil produtivo e dependencia das importacións podería ter graves problemas de abastecemento, como así sucedeu ${ }^{25}$.

Nos anos vinte aínda que segue publicando na Voz e esporadicamente en diversas revistas como a coruñesa Galicia Industrial y Comercial a influencia de Bartolomé Calderón está claramente en devalo ${ }^{26}$. Moitos dos seus puntos de vista tiñan sido incorporados nesas datas polo movemento agrarista e o nacionalismo pero paradoxalmente non recolle os froitos dese trunfo e a súa independencia e

\footnotetext{
${ }^{20}$ As nosas sospeitas a este respecto víronse confirmadas no artigo citado de ViLLANUEva "Una gran figura regional...".

${ }^{21}$ O seu derradeiro artigo é "Reflexiones sobre el comercio exterior español", PM, 224 (01-06-1912).

22 A Coruña, tipografía de El Noroeste, 1904, 123 páxinas.

${ }^{23}$ Madrid, 1906, 422 páxinas. Non lle coñecemos máis libros, non sendo o folleto divulgativo El gallinero: modelos y construcción, Madrid, Calpe, 1921, 31 páxinas.

${ }^{24}$ Mercedes Román Portas, "Aliadofilia y neutralidad en La Voz de Galicia en los años de la Primera Guerra Mundial”, Historia y Comunicación Social 18 (2013), páxs. 293-303.

25 "Alrededor de la guerra", PAP, 895 (15-12-1914) ou "La cuestión caballar en la actual guerra", PAP, 897 (31-12-1914). Para un achegamento historiográfico á cuestión, Alver OfFer, The First World War: an agrarian Interpretation, Oxford, Clarendon, 1989.

${ }^{26}$ Fundada en 1926, con periodicidade mensual e un talante modernizador, vencellada ó republicanismo herculino.
} 
lonxanía física de Galicia fan que estea desconectado do tipo de iniciativas prácticas nas que se involucrara nos primeiros quince anos do século. $\mathrm{O}$ movemento agrarista deixa atrás o modelo de Asembleas despois da tumultuosa da Coruña de 1919 e o paso do rexionalismo ó nacionalismo afasta a Calderón do galeguismo, co que malia as súas reticencias, que se analizarán a continuación, tiña un grande potencial de colaboración. Daquela, cando en decembro de 1931 atopándose accidentalmente en Burdeos sofre un problema de saúde e morre mentres era intervido cirurxicamente a nova a penas ten repercusión en Galicia, agás no xornal no que colaboraba dende trinta anos antes e na lembranza dalgún dos seus vellos compañeiros de inquietudes como Valeriano Villanueva ou Federico Maciñeira.

\section{Sen ETIQUetas: CARACTERIZACión IDEOlóXicA de BARTOlomé CALDERón}

Bartolomé Calderón foi ó longo da súa vida un polemista de lingua afiada e das súas críticas non saíu indemne ningún dos partidos políticos. Tampouco militou en ningunha formación non sendo na fase inicial das Irmandades da Fala, dato non concluínte posto que nos dous primeiros anos ata que se dá o paso explícito cara ó nacionalismo eran aínda unha iniciativa pouco definida que atraíu a persoas de moi diversas conviccións ${ }^{27}$. Malia todo, é posible facer unha caracterización ideolóxica de Calderón, que lonxe de ser un divulgador agrario dos que se limitaban ós aspectos técnicos entrou a fondo nas implicacións políticas e sociais das súas propostas. Aclaremos, iso si, que Calderón era un pragmático, que puña a política ó servizo da evolución que defendía para a economía galega e non ó revés, non deducía as reformas económicas necesarias dunhas posicións ideolóxicas previas. Por iso podía escribir que
Los que ponemos el derecho a la vida y el progreso humano ante toda y sobre toda otra consideración e interés, no debemos reparar para obtener nuestra independencia económica, en apoyarnos en cualquiera y en todas bases políticas conocidas, desde D. Carlos hasta Pablo Iglesias ${ }^{28}$.

Calderón entra en escena na resaca do Desastre cando o ambiente intelectual está dominado en España polo chamado Regeneracionismo, conxunto heteroxéneo de autores que tentan atopar as causas e as solucións da decadencia española evidenciada na nefasta xestión da crise cubana e a guerra cos Estados Unidos. Parte deste impulso canalizouse en Galicia, como pasará en Cataluña, a través do

\footnotetext{
${ }^{27} \mathrm{O}$ dato da afiliación de Calderón ás IF débollo a Justo Beramendi, autor da obra de referencia para o estudo do galeguismo; De provincia a nación, Vigo, Xerais, 2007.

28 "Nuestro progreso agrícola depende de nuestra independencia económica", PM, 106 (15-06-1907).
} 
rexionalismo, aínda que non faltasen aportacións ortodoxas á literatura rexeneracionista como Los desastres y la regeneración de España (1899) do republicano coruñés José Rodríguez Martínez, o médico Rodríguez.

Calderón colabora como vimos coa Unión Nacional de Joaquín Costa e Basilio Paraíso e a súa crítica ó Estado da Administración e ós valores e pasado nacional español é inmisericorde. As invectivas encaixarían perfectamente intercaladas nas obras de Lucas Mallada, o propio Costa ou calquera dos demais compoñentes da nómina de rexeneracionistas. Un exemplo representativo:

Todo lo que en España existe de bueno es la obra particular del ciudadano; por el contrario, todo lo que depende más o menos directamente del Estado, como la Instrucción pública en todas sus formas, el Ejército, la Marina y los arsenales, la recaudación de impuestos y la administración de justicia, etc., presentan la más detestable organización y son el foco de los mayores abusos. El gobierno no hizo,no hace, ni hará nunca nada en provecho de nuestra desdichada ganadería; si desgraciadamente interviniera sería para introducir algún nuevo error, crear algún nuevo vicio y empeorarlos todavía si fuera posible ${ }^{29}$.

O librecambismo, a crítica do latifundismo, o liberalismo e a aposta por un agrarismo modernizador como base para a prosperidade económica podería ser compartido tamén polo groso dos rexeneracionistas, sendo o notario de Frómista Julio Senador con quen as coincidencias son máis rechamantes ${ }^{30}$.

Un autor tan próximo a Calderón como Valeriano Villanueva é definido sen vacilacións por José Antonio Durán como "rexeneracionista", coa salvedade da súa falta de fe na acción política en contraste con $\operatorname{Costa}^{31}$. Cremos que Calderón e en xeral o grupo de Prácticas Modernas comparten cos rexeneracionistas un mesmo clima cultural de conciencia de decadencia, o desprezo cara ó sistema político da Restauración, a busca de referentes europeos e un trasfondo populista que diferencia entre un pobo (máis en concreto o campesiñado como no caso de Costa e non o proletariado industrial) incontaminado vítima dun sistema e unhas elites corruptas. A teima de Calderón contra as touradas como símbolo dos defectos

\footnotetext{
29 "La mejora de la ganadería y las corridas de toros" (anónimo pero con toda seguridade da autoría de Calderón), CT, 18 (1-11-1902). Un diagnóstico de España como "niño anémico" en El pan y el trigo..., páx.44 e ss.

${ }^{30}$ Eloy Fernández Clemente, "Bases teóricas de una política económica regeneracionista", en Vicente Salavert Fabiani e Manuel Suárez Cortina (eds.), El Regeneracionismo en España. Política, educación, ciencia y sociedad, Univ. De València, 2007, páxs. 81-124; Antonio Fernández SANCHa, Julio Senador: un pensamiento a contracorriente, Valladolid, Junta de Castilla y León, 2001.

31 Villanueva, Organización..., páx. 84.
} 
nacionais tamén era compartida, se cadra sen tanta virulencia, por Costa, Picavea ou Maeztu. E sen embargo Calderón desmárcase do Rexeneracionismo de maneira explícita en múltiples ocasións, por exemplo do seu proxecto estrela de regadíos, que denomina ironicamente "política acuática" ou "hidráulica" e considera unha fonte de corrupción e despilfarro.

Se necesita tener un aplomo extraordinario y considerar á los españoles como perfectos mentecatos para exigir de los contribuyentes enormes sumas que se emplearán en secanos cuyo excedente de la primera cosecha con riego paga el gasto de la transformación en regadios, como nos aseguran los apóstoles de la politica húmeda ${ }^{32}$.

Tampouco comparte outra das solucións comúns ós rexeneracionistas de toda condición, a énfase na educación. Para Calderón sería comenzar a casa polo tellado, posto que a prioridade serían as reformas económicas e posteriormente as propias estructuras produtivas reclamarían traballadores máis formados. Invertir esa orde só levaría á emigración de man de obra cualificada que non atoparía ocupación acorde coas súas capacidades ou competiría por subempregarse na burocracia estatal ${ }^{33}$.

Calderón contemplaba con escepticismo a batería de proxectos rexeneradores:

A raíz de la pérdida de nuestras últimas colonias, de una manera tan poco elegante como costosa y dolorosa, ha surgido el período que pudiéramos llamar de los proyectos de regeneración, en el cual lo menos la mitad de los españoles tenían cada uno en el bolsillo ó en la mollera la receta segura para convertir la nación en la potencia más poderosa y dichosa de Europa ${ }^{34}$.

A razón de fondo con todo era máis profunda. Detrás do Rexeneracionismo latexa un desexo de revitalizar a nación española, en clave máis ou menos esperanzada (cos extremos en Lucas Mallada - pesimista- e Macías Picavea -op-

\footnotetext{
32 "La miseria y la agricultura", PM, 66 (15-9-1905).

33 "Inglaterra, Francia y Alemania, cuando han aprendido á leer, es cuando sabían trabajar y sabían comer [...] Si el individuo que sepa leer o escribir fuera un elemento esencial ó útil en nuestra sociedad ya ésta se encargaría de producirlo con ó sin el auxilio del Estado"; "La panadería antes que la escuela", PM, 131 (1-07-1908). Na mesma liña "La lucha por la vida", PM, 30 (15-03-1904) e "La instrucción pública y el estado económico de la nación”, PM, 138 (15-10-1908).

34 "El fomento agrícola y sus resultados", PM, 208 (15-09-1911).
} 
timista-) con respecto ás posibilidades de poder medirse en pe de igualdade cos países punteiros de Europa. Calderón pola contra non cre na posibilidade dun rexurdir de España e parte dunha dicotomía radical maniquea entre a periferia da franxa cantábrica, Cataluña e País Valenciano, rexións de pequena e mediana explotación, e a España seca que controla o aparello do Estado e parasita as enerxías das primeiras, as únicas rexións verdadeiramente productivas e europeas que debían rachar "esa camisa nacional piojosa de barbechos, trashumancia y toros de lidia" ${ }^{35}$.

A visión do pasado de España é descarnada, unha descalificación sen paliativos das supostas glorias patrias que se pode atopar en moitos rexeneracionistas, pero aquí seica sen esperanzas de correxir os vicios do carácter hispano e as inercias acumuladas. Calderón ataca o patrioterismo ("Para nuestros escritores de rotativo, la patria es el resumen del odio universal y la esencia de todos los crímenes y crueldades que ha cometido la soldadesca de los tiempos pasados") ${ }^{36}$, compara con frecuencia a España co Imperio Otomano e contrasta desfavorablemente o legado do colonialismo español en América ("mancha infame de la Historia de la Humanidad") co anglosaxón ${ }^{37}$. Nunha metáfora moi característica, describe así a España:

\section{[...] en el rebaño de las naciones civilizadas modernas hacemos el papel del animal cojo al cual le sobra la mitad de la piel para cubrir sus tristes huesos y marcha siempre rezagado y cubierto de parásitos ${ }^{38}$.}

A simpatía polo rexionalismo catalán é proclamada en moitas ocasións:

[O progreso de Cataluña] se debe sobre todo á esa antipatía sal-
vadora que han tenido siempre los catalanes al poder central, á ese
asco, á ese odio provechoso que les ha inspirado la función oficial
y que les ha aislado eficazmente de la gangrena que corroe las otras
partes de la peninsula, del pólipo político que lleva la miseria y la
desolación á la agricultura como a todo lo que toca. En el Norte

\footnotetext{
35 "Los barbechos y la ganadería VII", PM, 54 (15-03-1905)

36 "El fomento de nuestra Agricultura precisa un espíritu á lo Tolstoi”, PM, 190 (15-12-1910). A crítica ó emprego do patriotismo por parte dos intereses cerealeiros de Castela contra os rexionalismos catalán, basco e galego en El pan y... pág. 72.

${ }^{37}$ Entre outros moitos exemplos en "La ganadería y la civilización", PM, 49 (1-01-1905): "España ha colonizado con sargentos, frailes, agentes de aduana y toreros" que convertían á metrópoli a ollos dos colonos nunha "madrastra odiosa"; a cita da "mancha infame" en "Sierra Morena o el nuevo arancel". PM, 83 (1-06-1906).

38 "La protección a la rutina", PM, 63 (1-08-1905).
} 
somos 5 ó 6 millones de ciudadanos tan inteligentes y trabajadores como los catalanes, y encontrándonos en condiciones ventajosísimas, en general, de clima y de terreno, no nos falta para ser ricos y dichosos más que combatir á muerte, como hacen aquéllos, los parásitos que nos explotan ${ }^{39}$.

As invectivas contra o centralismo e contra o predominio de Castela (outro aspecto clave no que difire do Regeneracionismo e das xeracións do 98 e o 14) no conxunto de España son unha constante:

No cabe la menor duda que la decadencia española y la ruína que parece amenazar á la nación, es en gran parte un efecto del predominio político de Castilla, el cual directa é indirectamente se opone al progreso material del país [...] Un espíritu histórico antisocial, antihumano, una falsa literatura, el quijotismo en todo lo que tiene de más soñador y perjudicial al arraigo y la multiplicación de las ideas que fomentan el progreso material. También el charlatanismo y el chanchullismo político q tanto perjudican el progreso español han tenido á Castilla como lugar predilecto [...] Una banda de Quijotes chiflados ha organizado hace poco en Madrid una fiesta en honor de la guerra de la independencia. La fiesta debiera haberse organizado con espíritu contrario, pues la invasión francesa ha resultado un bien para España, como hubiera sido hoy una ocupación inglesa que durante 30 años nos enseñara a pensar y trabajar [...] En el cacique castellano no solo encontramos ese odio sistemático é impulsivo al progreso que se observa en los jefes de las tribus árabes de África, sino además un deseo manifiesto, casi un instinto natural, a causar el mayor daño posible á la riqueza de las regiones vecinas ${ }^{40}$.

O centralismo tería graves consecuencias económicas, ó xogar a favor dos sectores máis retardatarios da economía española, que sen embargo controlaban a administración estatal no seu beneficio. Estas afirmacións e máis a continua contraposición en termos que se poderían denominar murguiáns (nun rexistro racial chocante dende a sensibilidade actual pero habituais nos medios intelectuais europeos e peninsulares de comezos do século XX) entre unha España celta e outra penalizada pola herdanza árabe poderían levar a clasificar a Calderón como rexionalista. De feito afiliouse como vimos ás Irmandades e algúns

\footnotetext{
39 "Las cartillas agrícolas y la emancipación rural", PM, 18 (15-09-1903).

40 “El señor feudal moderno castellano", PM, 214 (15-12-1911).
} 
artigos seus vanse publicar traducidos ó galego en A Nosa Terra en 1917-18. Calderón mesmo escribe da necesidade dun "rexionalismo agrícola" que permita desenvolver o potencial das rexións periféricas afogadas polo centralismo, que concibe a política agraria unicamente en termos de defensa do trigo e da gran explotación, aínda que fala indistintamente de Galicia ou do Norte de España como referente territorial:

No vemos ninguna nacionalidad en Europa, fuera de Rusia, incluso Austria, cuyo país tenga un carácter tan regionalista, cuyas partes geográficas sean menos homogéneas que en el nuestro, cuyos pedazos resulten tan mal pegados. Todo en la naturaleza tiende á separarnos, todo en la vida tiende á hacernos independientes. Esta diversidad del clima y del suelo, no es, sin embargo, un obstáculo insuperable para un régimen político común; para una vida económica en comandita y de armonía como lo es en muchos otros países y lo ha sido en otra época en el nuestro. El regionalismo intelectual español no ofrece caracteres de disolución de razas, de separación de sangre como pasa en Turquía y pasará mañana en Austria y Rusia. En España el regionalismo y el separatismo con la disgregación, la separación de los elementos sanos, de la superficie de un cuerpo cuyo centro está en completa putrefacción ${ }^{41}$.

Calderón saúda con grande entusiasmo o xurdimento de $S$ olidaridad $G a$ llega, pero con máis énfase no aspecto da expansión do societarismo agrario que na súa faciana política ${ }^{42}$. E sen embargo Calderón será moi crítico co rexionalismo galego, ó que achaca falta de sentido práctico e obsesión cos aspectos culturais e lingüísticos:

Nuestro regionalismo se reduce á lloriquear en versos, á pedir limosna en cuartetos; jamás un acto de virilidad, un arranque de energía, para reclamar tanto como se nos debe en nuestra cuenta económica, para defender tanto como se nos arrebata de nuestro patrimonio y de nuestra producción en provecho de todos los acaparadores, de todos los señores feudales, de toda la nación ${ }^{43}$.

\footnotetext{
${ }^{41}$ Nuestro progreso agrícola depende de nuestra independencia económica”, PM, 106 (15-06-1907).

${ }^{42}$ Miguel CABO, "Solidaridad Gallega y el desafío al sistema de la Restauración, 1907-1911”, Ayer, 64 (2006), páxs. 235-259.

43 "El regionalismo económico", PM, 114 (15-10-1907).
} 


\begin{abstract}
El regionalismo es hoy el último recurso al que podemos apelar para obtener la entrada libre de los cereales que permitirán alimentar las clases productoras con economía y transformar por completo el modo de ser del cultivo ${ }^{44}$.
\end{abstract}

E esa orientación práctica (que lle leva a poñer como exemplo de verdadeiro rexionalismo a Flora de Galicia do P. Merino ou a afirmar que "la primera bandera de nuestro regionalismo debería ser una corteza de pan") podería axudar a mobilizar ó campesiñado se vía defendidos os seus intereses, e efectivamente a conexión co movemento agrarista foi sempre a aspiración das IF e máis tarde do Partido Galeguista para acadar a condición de partido de masas ${ }^{45}$. O que xa non aceptou Calderón foi o paso do rexionalismo ó nacionalismo das IF na Asemblea de Lugo e a súa postura na cuestión lingüística non era tampouco a dun nacionalista galego, posto que era contrario á cooficialidade co castelán ${ }^{46}$. Aínda que consideraba que o galego podía ser unha ponte cara a Brasil e Portugal, opinaba que carecía de vocabulario científico, que podía resultar diminuído o dominio do castelán entre a poboación e que o progreso sempre fora da man de idiomas internacionais ${ }^{47}$.

Semella acertada a observación do antigo deputado liberal de Ortigueira Manuel Casariego no sentido de que "condenaba abiertamente el nacionalismo, pero propugnaba el autonomismo administrativo y económico"48. Malia todo, nestas cuestións Calderón non amosaba loxicamente a mesma coherencia que nos temas económicos e o mesmo pode referirse a Galicia como "región" que "nación", afirmar que España seguía o camiño do Imperio Habsburgo ou que Galicia era unha "colonia castellana". En 1923 asegura que na Península Ibérica só existían tres nacións: Castela, Cataluña e Portugal, e que Galicia podería incorporarse á esta última se seguían a non terse en conta os seus intereses económicos ${ }^{49}$.

Calderón tamén tiña evidentes simpatías co republicanismo en clave federal polas súas teses anticentralistas. $\mathrm{O}$ anticlericalismo tamén formaba parte da bagaxe da cultura política republicana, aínda que en Calderón non acada a virulencia característica doutros autores ${ }^{50}$. Tampouco escasean as referencias despectivas

\footnotetext{
44 "Nuestro progreso agrícola depende de nuestra independencia económica”, PM, 106 (15-06-1907).

45 A cita procede de "El regionalismo material", PM 175 (1-05-1910).

${ }^{46}$ Emilio X. ÍnsuA, A Nosa Terra é Nosa! A xeira das Irmandades da Fala (1916-1931), A Coruña, Baía Edicións, 2016, páx. 274.

47 "El gallego puede ser útil a la nación, mas hay que huir de la confusión de lenguas", VG (19-06-1931).

48 Manuel CaSARIEGo, "Valores de casa. Bartolomé Calderón”, VG (21-04-1935). Casariego militaría no Partido Radical durante a II República.

49 "El problema catalán", VG (8-04-1923). Sorprende a non mención de Euskadi pero en efecto a penas recibe a atención de Calderón, suponse que por falta de afinidade ideolóxica co nacionalismo vasco.

${ }^{50}$ Un anticlerical típico nunca lamentaría que os cregos en España se involucrasen pouco no sindicalismo e a divulgación agrícolas como si facían nalgúns países estranxeiros; "El cura de aldea y la agricultura", PM, 159 (1-09-1909).
} 
cara ós monarcas do século XIX, pero co pragmatismo que lle caracteriza a forma de goberno sempre é unha cuestión secundaria fronte ás consideracións económicas. Nun artigo de 1917 amósase partidario dunha solución iberista para as relacións España-Portugal, outra pista no sentido do republicanismo federal, coa condición previa de que España superase o seu centralismo ${ }^{51}$. E en todo caso os republicanos tampouco se libraban dos seus dardos dialécticos pola súa falta de sentido práctico ("El partido republicano gallego nos hace el efecto de una ostra encerrada en las ciudades entre una concha socialista y otra de funcionarios públicos") ${ }^{52}$. As poucas mencións que fai do socialismo son negativas polos efectos nocivos das folgas, aínda que tamén concede a Pablo Iglesias unha louvanza respectuosa cando se opón á suba de aranceis ${ }^{53}$.

Sobre os partidos dinásticos Calderón non ten máis que referencias descualificadoras, sen matices que diferencien entre liberais ou conservadores ou entre as diferentes faccións que os compuñan, nin sequera das que pretendían renovar a praxe política como mauristas ou canalejistas.

En resumidas contas, Calderón podería ser encadrado no espazo compartido por rexionalistas e republicanos federais. Unha derradeira observación: en contraste con moitos rexeneracionistas españois, Calderón nunca se víu tentado de propor unha dictadura que implantase as reformas que defendía. Debaixo das súas críticas ó sistema da Restauración non se agochaba, como en tantos outros, un rexeitamento do parlamentarismo. Os seus referentes ideais (principalmente Reino Unido e Dinamarca) tamén apuntan nesa dirección.

\section{O PENSAMENTO ECONÓMICO DE BARTOLOMÉ CALDERÓN}

Os primeiros escritos coñecidos de Bartolomé Calderón publícaos con case corenta anos. Isto explica que o seu pensamento aparecese xa plenamente configurado e se mantivese constante ó longo do tempo, polo que non é pertinente diferenciar entre diversas etapas xa que non se produce evolución ningunha no sustancial, como moito adaptacións ós acontecementos que se van producindo en Galicia ou no mundo. Non estamos a falar da obra dun economista teórico, exposta sistematicamente en forma de tratados, senón de reflexións e posicionamentos espallados ó longo da súa extensa produción xornalística. Na súa liña pragmática, Calderón apoiase decote en exemplos do estranxeiro ou da historia que apoien as súas ideas e moito menos na teoría económica ${ }^{54}$.

\footnotetext{
51 "Portugal e Galicia", A Nosa Terra, 30 (1917).

52 "El regionalismo económico", PM, 114 (15-10-1907).

53 "Los señoritos en la economía social española", PM, 126 (15-04-1908).

${ }^{54}$ Unha desas excepcións é cando se apoia en Adam Smith para preconizar o librecambismo en El pan y el trigo..., páx. 42 .
} 
Para comezar, Calderón podería ser calificado como materialista no sentido de que a economía condiciona todas as demais esferas da actividade humana, e neofisiócrata posto que considera que o sector agrario é a base dunha economía sólida:

Todas las grandes revoluciones, todas las grandes luchas de la humanidad no han sido más que una cuestión de comida, más o menos directa o disfrazada. ¿Qué nos importan hoy a nosotros las libertades politicas, que de hecho no existen ni pueden existir? La religión, el sufragio, la justicia, la libertad personal, todo ha sido, es y continuará siendo un mito entre tanto no se nos otorgue la independencia del trabajo, la libertad de comer ${ }^{55}$.

La agricultura es la creadora de fortuna por excelencia, es el verdadero material de riqueza, es la industria que puede ser más ó menos productiva, más o menos económica o remuneradora, pero que no engendra nunca miseria, ni se forma á espensas [sic] de otra riqueza ya formada ${ }^{56}$.

Pero dentro do sector agrario a gandería ten claramente a preeminencia, o seu desenvolvemento marca a diferencia no presente entre os países e no pasado entre as culturas (por exemplo a inferioridade técnica e económica dos indíxenas de Australia ou os pobos amerindios) ${ }^{57}$. No caso concreto de España o pecuario sería o seu principal problema económico posto que en número de cabezas e productividade saía perdendo na comparación cos países veciños e esa debilidade condicionaba os baixos rendementos cerealeiros ${ }^{58}$. Ademais unha gandería forte crearía un círculo virtuoso coa agricultura proporcionándolle esterco ("la primera fábrica de nitratos que debemos montar en España es la de la vaca alimentada con leguminosas") e forza de tiro, daquela considera que sería a vía pola cal mellorar a agricultura da España seca e superar o barbeito ${ }^{59}$. Sen embargo Calderón non é hostil á industria como sucede por exemplo cunha parte dos pensadores das

\footnotetext{
55 "El regionalismo desempeña un importante papel en nuestro progreso material”, PM, 108 (15-07-1907). 56 "La riqueza pública y sus parásitos", PM, 89 (1-09-1906).

57 “La ganadería y la civilización”, PM, 49 (1-01-1905); "Variación animal”, PM, 73 (1-01-1906): "Los países que tienen una ganadería miserable son pueblos pobres y moralmente degenerados; por el contrario, no hay pueblo ilustrado y medianamente trabajador en el mundo (y la regla no tiene excepción alguna en la historia) que no haya transformado la naturaleza de sus ganados en el sentido que permite y exige el progreso".

58 Fomento de la... páx.2; "La cuestión pecuaria en el Norte de España”, PM, 29 (1-03-1904).

59 "La importación de abonos nitrogenados y la ganadería agrícola", PAP, 508 (22-11-1906).
} 
Irmandades, de feito as súas referencias máis recorrentes son dous países industrializados, cada un ó seu xeito, Gran Bretaña e Dinamarca.

Esta última é a que podería ofrecer un modelo máis realista para a economía galega posto que se tería modernizado a partir da agroindustria e a vocación exportadora, unha fascinación compartida por moitos ${ }^{60}$. Un primeiro paso sería a existencia de matadoiros en orixe que permitisen superar os tradicionais envíos de gando en vivo ós mercados peninsulares, que se vai converter nunha aspiración do movemento agrarista que terá finalmente plasmación en 1928 (aínda que cunha xestión desafortunada) co matadoiro cooperativo de Porriño impulsado fundamentalmente polo sindicalismo agrícola católico. En segundo lugar Bartolomé Calderón dende o primeiro momento é un decidido partidario da orientación láctea da gandería para a produción en orixe de manteiga, queixos, leite condensado e gandería porcina intensiva (co leite descremado sobrante), seguindo o modelo dinamarqués. Tamén noutros produtos avoga por completar o ciclo produtivo en Galicia, como nos ovos, conservas de froitas e hortalizas ou sidrerías e exportar ó mercado español pero sobre todo ós europeos ${ }^{61}$.

En segundo lugar, contra a ortodoxia liberal e marxista que prevían a súa desaparición futura Calderón, ó igual que Valeriano Villanueva aínda que sen chegar ós seus extremos, é un defensor da pequena e mediana explotación, e non por motivos extraeconómicos como en tantos outros autores e ideoloxías que louvan dela o seu aporte á orde social, á estabilidade, ó mantemento das tradicións, á puxanza demográfica, etc. Calderón considera que a pequena explotación (na medida do posible coincidente coa propiedade) é perfectamente viable. Do mesmo xeito confía na capacidade dos labregos galegos ("mano de obra admirable, inteligente, resignada, trabajadora como no existe ninguna en España y pocas en otros países") para entrar de cheo na innovación técnica se se lles facilitan as condicións axeitadas para facelo e co cooperativismo como instrumento clave para crear economías de escala ${ }^{62}$. Esta confianza verase reforzada a medida que se vaia consolidando o movemento agrarista. Como no caso do seu amigo Villanueva, de xeito independente chega a unha reivindicación da lóxica campesiña que lembra ás teses do ruso Chayanov ${ }^{63}$.

\footnotetext{
${ }^{60}$ Miguel CABO, "Mirando cara ó Norte: a fascinación por Dinamarca na Galiza do primeiro terzo do século XX”, Murguía. Revista Galega de Historia, 32 (2015), páxs. 83-92.

${ }_{61}$ "El precio de los productos agro-pecuarios gallegos", VG (2-03-1918); "El progreso agrícola en el Norte de Europa y el atraso de Galicia", Follas Novas (A Habana), 374 (31-07-1904); "Intereses gallegos", Heraldo de Galicia (A Habana) (23-05-1920). Na VII Asemblea Agraria (A Coruña, 1919) aprobouse un traballo seu titulado Beneficios que reportarían a la riqueza de esta región los molinos harineros, las fábricas de aceite y los mataderos industriales que faltan y debieran existir en gran cantidad en Galicia, VG (19-08-1919).

62 “Los sindicatos gallegos", PM, 129 (1-06-1908).

${ }^{63}$ Lourenzo Fernández Prieto, Antonio Bernárdez e Miguel Cabo, "Valeriano Villanueva y la lógica de la pequeña explotación agraria familiar contemporánea", en M. Aguilar Villagran, et. al. (eds.), Home-
} 
A pequena explotación tiña maiores rendementos e sostiña densidades máis altas de poboación, mentres o latifundio era "un verdadero despojo social"

Es en la propiedad media y pequeña en donde pueden fundarse esperanzas serias de regeneración agrícola; es esta sola la que puede salvar el país de la derrota económica y de la miseria social. Echemos una ojeada por el suelo español y veremos, lo mismo en Galicia que en Cataluña, en León o Álava, en Santander o Valencia, el pobre paisano, por el cual nunca nadie ha hecho nada, cultivar intensivamente la tierra, retirar del suelo la mayor y la mejor parte de nuestra producción rural, pagar la casi totalidad de las contribuciones, hacer vivir una familia en un pedazo de tierra que en manos de un gran cacique castellano, extremeño o andaluz no produciría para vivir un carnero ${ }^{65}$.

Calderón pode ser caracterizado como un liberal dende o punto de vista económico. Unha e outra vez denuncia os efectos perniciosos da intervención do Estado na vida económica, e non só cando se refire a España, senón tamén cando expresa o temor a que os mecanismos de control establecidos polos países belixerantes non se desmantelen unha vez rematada a Gran Guerra. O seu ideal é un Estado mínimo que se limite a garantir as condicións para o desenvolvemento económico, e só acepta iniciativas dos chanzos inferiores da Administración (concellos e deputacións) en colaboración con organizacións sociais, por exemplo apoiando concursos de gando ou paradas. Como bo liberal, atopa a competencia positiva, posto que incentiva ós países e ás persoas a especializarse naquelo no que posúan vantaxes comparativas.

La competencia comercial, la lucha por la vida, harán dar a la agricultura de cada región el carácter especial que le conviene según su naturaleza y relaciones; nosotros transformaremos nuestra economía rural en el sentido de la producción animal, de la cual cambiaremos una parte contra cereales, vinos, etc. en los mercados de Castilla, en el mercado inglés y en otros ${ }^{66}$.

\footnotetext{
naje a Antonio Cabral Chamorro, Historiador (1953-1997), Trebujena, Centro de Estudios y Documentación, 1998, páxs. 255-274.

64 "El latifundio y la pequeña propiedad rural", PM, 121 (1-02-1908).

65 "El ganado en la economía rural de Castilla", PAP, 492 (22-07-1906).

66 "Nuestro progreso agrícola depende de nuestra independencia económica", PM, 106 (15-06-1907).
} 
Por este motivo, e a diferencia de tantos outros ruralistas que invocarían motivos extra-económicos, Calderón non tería inconveniente en deixar sucumbir ós agricultores que non soubesen sacar o máximo partido da súa explotación unha vez se lles facilitasen as condicións para facelo. Nas súas palabras, "lo que se debe proteger no es la agricultura, es el progreso agrícola"67. Malia residir en Francia, o seu modelo ideal de economía é o británico e como espello máis achegado ás características de Galicia a exitosa Dinamarca, námbolos dous casos economías liberais:

\begin{abstract}
Pues el danés, como el inglés, no pide que haga el Estado lo que puede hacer él mismo, tiene horror á la intervención oficial en la industria privada. Es lo contrario de lo que pasa en nuestro triste país, que poco falta para que se pida a los Poderes públicos que vengan á regar el trigo y ordeñar las vacas de cada vecino ${ }^{68}$.
\end{abstract}

Todo o anterior conleva loxicamente o librecambismo. Calderón vaise atopar coa mesma contradición que os nacionalistas galegos: proclamar as bondades do libre comercio e a capacidade de Galicia para competir sen aranceis e ó mesmo tempo condear calquera decisión que implique o abaratamento da entrada de carne conxelada estranxeira. Calderón tenta saír da mesma argumentando que mentres existise proteccionismo para os bens que Galicia necesitaba para o seu desenvolvemento non era xusto que se deixasen de gravar xusto as importacións que máis podían afectarlle ${ }^{69}$. O proteccionismo era dobremente nocivo en España porque estaba argallado en beneficio dos grandes productores de cereais, que podían así vender a súa produción a prezos moi superiores ós do mercado mundial en prexuízo de consumidores e gandeiros. Noutros sectores tamén se daban situacións de monopolio e prezos artificialmente elevados como nos tecidos, no sucre, carbón... De rebote, as lóxicas contrapartidas dos terceiros países fronte ós aranceis (que efectivamente se contaban entre os máis elevados de Europa dende o xiro de 1891) puñan en dificultades ás industrias de perfil exportador como os cítricos valencianos ou as conservas galegas. Outro efecto dos aranceis elevados era gravar a importación de inputs necesarios para a mellora técnica da agricultura e a gandería (adubos, maquinaria, reproductores selectos...) cuxa demanda a industria española cubría insatisfactoriamente.

\footnotetext{
67 “El arancel y la rutina agrícola”, PM, 17 (1-05-1905); “La protección á la rutina”, PM 63 (1-08-1905); "La ganadería española", PAP, 480 (22-04-1906).

68 "La agricultura en Dinamarca. Suelo, clima y habitantes", PM, 137 (1-10-1908).

69 "El comercio exterior del ganado vacuno en España y el arancel”, PAP, 476 (22-03-1906); "Sierra Morena ó el nuevo arancel”, PM, 83 (1-06-1906).
} 
El comercio, libre de toda traba adecuada [sic], es la única forma que se presta al mejor aprovechamiento de las riquezas naturales de cada país, al bienestar humano, y á la desaparición de contiendas internacionales. El libre cambio es la fórmula económica, internacional, indispensable al progreso humanitario del mundo ${ }^{70}$.

O librecambismo sería unha condición para a prosperidade pero tamén constituiría algo máis, unha verdadeira distinción entre as economías competitivas e as condeadas a sobrevivir precariamente protexidas tras os muros invisibles dos aranceis e adiando as reformas necesarias. Por iso cando Calderón argumenta que a Galicia lle conviría un réxime librecambista está proclamando por unha banda unha visión optimista da economía galaica, que podería competir cara a cara coas outras economías atlánticas, e pola outra suliñando a súa superioridade sobre a meirande parte de España refuxiada no parapeto do proteccionismo.

\begin{abstract}
[...] nuestra región no es la llanura de la Mancha ó de Extremadura en donde el principio de la vida económica se funda en la condenación del progreso industrial y el aislamiento de la actividad y la intensidad de la vida exterior. No, somos un pueblo de trabajadores colocados en el medio más fértil y más propicio al desarrollo de la riqueza y del bienestar humano. Seremos mañana un pueblo rico y dichoso como Dinamarca, si se nos permite vivir y trabajar como esta nación $n^{71}$.
\end{abstract}

O camiño para Galicia estaba claro. Tanto o medio físico como o social aconsellaban reducir drasticamente os cereais, que se poderían importar, concentrarse en pratenses e forraxeiras e poñer todo o sector agrario ó servizo da especialización gandeira, en particular láctea. $\mathrm{O}$ destino sería fundamentalmente a exportación ó mercado británico e outros europeos, aproveitando os excelentes portos e a cercanía xeográfica, mentres os envíos ós mercados peninsulares estaban penalizados polas deficientes comunicacións e os intermediarios.

Plans tan ambiciosos requerían dunha renovación técnica que para Calderón descansaría sobre todo nos concursos de gando, nos que se involucrou na práctica todo o grupo de Prácticas Modernas. Na polémica sobre a mellora da cabana vacuna Calderón apostaba decididamente pola selección das razas propias (non sendo cruces con fins moi específicos) e non a través da introdución de razas

\footnotetext{
70 "El arancel y el fomento agrícola", PM, 81 (1-05-1906).

71 "La agricultura en Dinamarca", PM, 136 (15-IX-1908).
} 
estranxeiras, e os avances chegarían tamén coa mellora da alimentación e os coidados $^{72}$.

No relativo á cuestión da propiedade, Bartolomé Calderón asiste ó paso do problema foral de cuestión xurídica a cuestión social. En termos xerais é contrario a dito contrato, pero ocupa un lugar menor dentro das súas preocupacións, moi por debaixo da atención reservada a cuestións produtivas. Latexa o temor a que a cuestión foral polo seu dramatismo e o seu potencial político monopolice toda a atención nos debates sobre a economía galega e ademais que a redención de rendas absorba os capitais e o esforzo que requerirían as reformas do cultivo e a gandería. Dito isto, Calderón oponse ó foro, contrapoñéndolle a propiedade campesiña como forma ideal de ocupación da terra, considera que as rendas son excesivas e que é unha das causas, aínda que non a principal, da emigración. En Calderón non se atopan as louvanzas ó papel histórico do foro tan comúns no seu compañeiro de andainas xornalísticas, o tradicionalista Amador Montenegro Saavedra, e tamén en moitos nacionalistas. A súa principal preocupación era que cando a presión das sociedades agrarias fixese inviable o mantemento do status quo se pechase en falso o conflito cunha lei que salvagardase os intereses dos rendistas e empurrase ós foreiros ás mans dos usureiros, e como sempre tamén aquí confía moito máis nas solucións dende a sociedade civil que dende o Estado $^{73}$.

Polo que atinxe ó sector forestal, Calderón nas ocasións nas que se referíu ó tema amosouse escéptico, non necesariamente hostil, cos plans de repoboación porque non confiaba en que o Estado financiase dabondo os proxectos e sobre todo porque entrarían en contradición cos aproveitamentos do monte polos labre$\operatorname{gos}^{74}$. Cando a rendabilidade dos produtos gandeiros medrase xa daría comezo a reconversión voluntaria de parte das terras a monte a pratenses e forraxeiras.

De feito tanxencial Calderón ocúpase doutros sectores, como o turismo ou a pesca, sempre coa vista posta na modernización da economía galega e na relación con Europa ${ }^{75}$. As comunicacións serán outras das súas preocupacións permanentes, tanto polo que se refire á denuncia das existentes coa Meseta como no impulso ó

\footnotetext{
72 "La selección del ganado bovino del Norte", PM, 88 (15-08-1906); "La cuestión del ganado", Eco de Galicia 144 (5-06-1921). Para unha panorámica xeral destas cuestións, Conde Gómez, Canto val... páxs. 93 e ss.

73 "El latifundio y la pequeña propiedad rural", PM, 121 (1-02-1908); "Los intereses de la pequeña propiedad agrícola", PM, 133 (1-08-1908); "Los foros”, PM, 212 (15-11-1911); "La redención de los foros. Maldad del proyecto", Suevia, 2 (8-03-1913).

74 “A propósito del próximo congreso en Santiago", Eco de Galicia, 150 (21-08-1921). Si é partidario de eliminar as prácticas de gandería extensiva cabalar e vacuna en prol da estabulación.

75 "Sobre la industria pesquera", VG (18-12-1917) onde sostén a necesidade de modernizar os aparellos e consolidar as industrias derivadas, en contraste co que tería pasado na Bretaña onde por terse protexido a pesca a xeito tradicional o sector quedara estancado.
} 
ferrocarril da costa, ou defendendo o valor estratéxico dunha conexión ferroviaria directa con Francia para converterse grazas ós nosos portos en vía de entrada do comercio europeo con América ${ }^{76}$.

\section{UNHA OLLADA INCONFORMISTA SOBRE A SOCIEDADE E A CULTURA}

O liberalismo no eido económico de Calderón non se traduce no eido social, como sería previsible, nun individualismo extremo, senón que avoga polo asociacionismo nas súas diferentes modalidades como contrapeso ó poder estatal e para acometer tarefas que non estaban ó alcance dos individuos. Mentres desconfía do autonomismo político, propón a creación de organismos a escala galega na banca, o comercio, a industria ou o profesorado ${ }^{77}$. A proba está no entusiasmo co que saúda a emerxencia do movemento agrarista ${ }^{78}$. Para el as organizacións de agricultores serían a panca para resolver moitos dos problemas que sinalaba nos seus artigos. Calderón apostaba por sociedades apartidistas pero non apolíticas, posto que deberían presentar candidatos agrarios ós concellos e logo a Cortes (para "deshacerse de los diputados lacayos que son la deshonra de nuestra región") para defender as medidas requeridas para o avance económico de Galicia, con énfase nas melloras técnicas e no cooperativismo. Unha definición moi próxima pois á da Solidaridad Gallega e por esa vía extirparíanse as raíces do caciquismo ${ }^{79}$. En definitiva, co agrarismo "aparece claramente la aurora de la emancipación de nuestra democracia rural" 1 . Aínda que sen dúbida a Solidaridad é a organización agraria coa que máis se identificou, Calderón tivo eco en todo o espectro agrarista, agás no confesional. Tanto é así que o líder da anarquista Unión Campesina, Manuel Martínez Pérez, sen coñecerse persoalmente, louvou a súa figura en varias ocasións, en particular por ser partidario como el dunha federación agraria de todo o Norte peninsular ${ }^{81}$.

Calderón deposita unha grande confianza no aporte das mulleres á renovación social e económica, destacando regularmente o seu papel nas industrias rurais (avicultura, horticultura...) e o rol asumido por mor da emigración. Cando se ocupa da cuestión máis polo miúdo, faino aplicando a habitual dicotomía entre

\footnotetext{
${ }_{76}$ Baldomero Cores Trasmonte, "O tren dos tres 'CCC'”, Anuario Brigantino, 28 (2005), páxs. 239264; "Los grandes resortes de nuestro impulso económico”, Galicia Agrícola, 57 (06-1916).

77 "La autonomía gallega. Como elemento económico sí, para campo de discordias no", VG (11-01-1919).

78 Miguel CABo, O agrarismo, Vigo, A Nosa Terra, 1998; Isidro Román Lago e Antonio BernáRdeZ SobreIRA, Labrando na rebelión, Vigo, A Nosa Terra, 2007.

79 "Los beneficios políticos de las asociaciones agrícolas en Galicia”, PM, 119 (1-01-1908); "Los sindicatos gallegos", PM, 129 (1-06-1908); "Los sindicatos en la redención de nuestra economía rural”, PM, 130 (15-06-1908); “Los foros”, PM, 212 (15-11-1911).

80 "La obra de los sindicatos gallegos, PM, 134 (15-08-1908).

81 “La cuarta asamblea agrícola gallega. ¿Cuándo se celebra?”, VG (22-06-1912). Xa como líder da Unión Mutualista Campesina Martínez expresará o seu pésame no mesmo xornal o 6 de decembro de 1931.
} 
as rexións norteñas e o resto, expresada en termos étnicos. No Norte, Galicia incluida, "podemos ver á cada paso a la mujer inglesa, la normanda y sobre todo la irlandesa y la bretona", coa mesma capacidade de xestionar a explotación ca os homes e máis aínda cando reciban instrucción axeitada, mentres no Sur "las costumbres árabes han reducido la mujer poco menos que al estado de cosa, al papel material de máquina de producir hijos" $"$.

Un tema candente na época era o das causas e os efectos da emigración. Calderón a penas entra neste debate porque para el era a consecuencia inevitable dos problemas de fondo da economía española, polo que non tiña sentido combatila en si mesma se non se amañaban as causas estruturais que estaban na súa orixe ${ }^{83}$.

Para rematar este apartado, cómpre mencionar un tema que pode semellar anecdótico pero que no caso de Calderón acadaba a categoría de auténtica obsesión. Trátase das touradas, cuxa crítica era moi común nos ambientes republicanos e tamén dende o galeguismo e o catalanismo. Para Calderón era moito máis ca unha práctica brutal, pois constituía un dos motivos do atraso económico e cultural de España porque se interpuña no camiño da difusión dunha mentalidade de bo trato ó gando, inmobilizaba grandes superficies de terreo para a cría de reses bravas e mesmo daba lugar a un aumento da criminalidade. Era para el ó mesmo tempo a mellor demostración do retraso de España con respecto a Europa e da superioridade de Galicia e en xeral o Norte posto que aquí a afición era moito menor e inducida dende os medios madrileños ${ }^{84}$. Calderón adícalle ós touros o máis implacable da súa dialéctica, que lembra á do principal propagandista antitaurino da época, Eugenio Noel. Saca a colación a súa teima á menor ocasión, por exemplo se informa das novidades nun concurso de gando en París non deixa de sinalar que "Al ver estas escenas no puede uno menos de pensar que en el mismo momento un puñado de estúpidos y sanguinarios se divierte en España martirizando estos útiles animales y educando al pueblo en los sentimientos de barbarie y bestialidad que labran su ruina"85. En tanto non puidese ser abolido, avogaba por un imposto específico que se empregase para o fomento pecuario.

$\mathrm{O}$ estilo incisivo e inxenioso de Calderón aportaba amenidade mesmo a temas áridos e sen dúbida explica en boa medida o seu éxito xornalístico pero tamén lle

\footnotetext{
82 "Las mujeres en la agricultura del Norte de España", PM 15 (1-08-1903).

83 "La emigración es el trabajo huyendo del acaparamiento", PM, 120 (15-01-1908); "La emigración", PM, 169 (1-02-1910).

${ }^{84}$ Entre outros moitos, "La decadencia de la ganadería en España”, PM, 9 (1-05-1903); “Al Consejo de Estado", PM, 53 (1-03-1905); "Para hacer progresar la ganadería necesitamos los concursos de ganados", PM, 62 (15-07-1905) e de xeito máis sistemático en Fomento... páxs. 4-11 e 31-52.

85 "El concurso anual agrícola de París", PM, 56 (15-04-1905).
} 
levou a protagonizar numerosas polémicas, as principais das cales reseñaremos agora porque contribúen a comprender mellor ó noso personaxe $\mathrm{e}^{86}$.

O 8 de xullo de 1906 Emilia Pardo Bazán asina un artigo en La Voz de Galicia respondendo a unha enquisa sobre o suposto incremento da violencia e a criminalidade na Coruña e a escritora elenca diferentes causas (alcoolismo, facilidade para a adquisición de armas, cultura masculina da violencia...). Este último punto é o que desencadea a resposta de Bartolomé Calderón, que diferencia entre o "matonismo" que sería "la sangre torera, el espíritu chulo, el alma flamenca, que vienen a infertarse sobre un fenómeno animal común á todos los pueblos, á todas las épocas, á toda la vida animal en general" e unha violencia sá, que encauzaba a enerxía dos mozos como noutros países o faría o deporte, que serían as liortas entre pobos veciños que non lles impedían posteriormente convertirse en bos pais de familia porque era unha violencia que reforzaba as estruturas sociais e familiares ${ }^{87}$. Calderón contempla con comprensión determinadas formas de violencia, que considera sempre preferibles á sumisa resignación. Polo mesmo motivo simpatizará cos asaltos a almacéns durante os anos da Gran Guerra como reacción contra a especulación ou cos motíns de consumos, posto que verá nestas explosións a demostración de enerxías susceptibles de ser canalizadas de xeito máis construtivo:

\section{[...] es de ver como las garitas de consumos ruedan por el suelo ó son presa de las llamas a la primera manifestación de un desorden público. Los que hacen esto es la parte más interesante y más sana de la sociedad, a la cual le queda todavía el soplo de la virilidady el instinto de la lucha por la vida ${ }^{88}$.}

En xullo de 1909 nunha das súas colaboracións para Prácticas Modernas Calderón combina unha das súas teimas máis características, a antitaurina, coa crítica anticlerical, que asoma nos seus escritos de xeito esporádico. No remate, a propósito da presencia de bispos nos palcos de honor nos cosos, conclúe:

\section{Si el hijo de María volviera al mundo y viera la España católica convirtiendo en un colosal negocio nacional el martirio de los}

\footnotetext{
${ }^{86}$ Estilo atípico nos medios técnicos e que Juan Alvarado, impulsor das industrias lácteas en León co que colaborou en varias ocasións, calificaba como "excesivo encarnizamiento". Juan Alvarado y Albo, Epistolario, Villablino, Asociación Xeitu, 2014, páx. 542.

87 “El matonismo en La Coruña. A la señora Pardo Bazán”, PM, 87 (1-08-1906) e PM 90 (15-09-1906). Calderón adianta posteriores interpretacións dende a antropoloxía; Miguel CABO e Xosé M. VÁzQUEZ VARELA, "Las otras guerras de nuestros antepasados. la violencia comunitaria en la Galicia rural contemporánea”, Hispania, 251 (2015), páxs. 781-804,

88 "El trust del azúcar y los productores de remolacha”, PM, 152 (15-05-1909).
} 
pobres animales que han calentado su cuerpo con su aliento el primer día de su vida, iqué pensaría del porvenir de la Humanidad; ¿qué diría el Cristo, ese gran espíritu de justicia y de bondad, de los prelados y de las grandes eminencias de su Iglesia que han tomado bajo su protección este vicio social tanto más asqueroso cuanto que es un fruto de la avaricia y de la ferocidad del hombre moralmente degenerado? ${ }^{89}$.

O párrafo é representativo no sentido de que Calderón sempre diferencia entre a mensaxe evanxélica e a Igrexa como institución. En todo caso, o artigo non pasa inadvertido e dende o xornal católico coruñés El Eco de Galicia Manuel Comellas denuncia "ese espíritu agresivo que se manifiesta en la pluma del redactor más importante de Prácticas Modernas [...] impropio de una revista técnica" e chama a lectores e suscriptores católicos a boicoteala, non sabemos con qué resultado pero en todo caso creando unha situación incómoda para unha revista que malia os seus vencellos con republicanos e solidarios tentaba non verse involucrada nas disputas partidistas ${ }^{90}$.

O debate con máis trasfondo polo tema e o medio no que se desenvolve é o que mantén nas páxinas de El Progreso Agrícola y Pecuario entre finais de 1910 e principios de 1911 con José Gascón. Gascón era o director da Escola Práctica de Agricultura de Palencia e un dos (poucos) técnicos estatais que merecía o seu respeto, entre outras cousas porque defendía o aumento do gando bovino na Meseta. Gascón reacciona contra unha serie de artigos de Calderón replicando que tiña "un desconocimiento absoluto de Castilla, en la que no ve más que una región dominadora que se place en el mal de las otras, como si ella no sufriera más que ninguna, quizá por haber dado vida á tantas". O barbeito e o dominio dos cereais en Castela era para Gascón resultado das condicións climáticas, que tamén puñan serios límites ós prados, e non do arancel. De suprimirse este como defendía Calderón o resultado sería a despoaboación e a concentración do cultivo nas mellores terras, que era o que sucedera nos países librecambistas que Calderón puña como exemplo, daí os seus elevados rendementos ${ }^{91}$. Calderón insiste nas súas posicións, considera que o retroceso do cereal sería fundamentalmente no Norte e que sen o arancel as provincias da España seca veríanse forzadas a aplicar melloras técnicas para competir e a combinar gandería e agricultura para reducir o barbeito.

\footnotetext{
89 "El arte del toreo ó de sacar dinero de la bestialidad humana", PM, 156 (15-07-1909).

90 Manuel Comellas, "Prácticas Modernas y sus lectores católicos", El Eco de Galicia (29-07-1909).

91 José GASCón, “¿Cuál es la verdad?, PAP, 707 (15-01-1911) e co mesmo título outro en PAP, 715 (1503-1911); Bartolomé CALDERón, “Carta abierta a D. José Gascón”, PAP, 711 (15-02-1911) e “¿Cuál es la verdad?”, PAP, 721 (30-04-1911).
} 
Polas mesmas datas polemiza en Prácticas Modernas cunha das máximas autoridades da veterinaria española da época, Césareo Sanz Egaña. Calderón criticara que en congresos de veterinaria se ocupasen do gando trashumante ou se admitise nos concursos no canto de posicionarse radicalmente en contra de dita práctica, que para el era un síntoma inequívoco de atraso. Egaña replica que aínda que remataría por desaparecer mentres existise había que previr que propagase andazos ${ }^{92}$. A cuestión de fondo é a desconfianza de Calderón cara á independencia dos técnicos dos servizos oficiais pola súa lealdade á administración ou no caso dos veterinarios a un dos seus alvos predilectos, a Asociación General de Ganaderos del Reino ${ }^{93}$.

\section{UNHA INFLUENCIA SEN DEREITOS DE AUTOR}

A influencia de Calderón foi máis alá da súa intensa actividade xornalística, sendo esta dunhas dimensións extraordinarias á altura do outro gran polígrafo da veterinaria en Galicia, Juan Rof Codina. Ademais de en La Voz de Galicia e nas revistas técnicas que se foron citando, Calderón colaboraba na prensa da emigración e na vencellada ó movemento agrarista. Tanto é así que nalgunha ocasión tanto La Voz de Galicia como PM tiveron que denunciar o feito de moitas revistas reproduciren os seus artigos sen citar a fonte. A excepción foron os periódicos editados polos sindicatos agrícolas católicos, nos que non aparecen traballos seus con contadísimas salvedades de artigos de perfil técnico, o que non exclúe as coincidencias cos seus postulados ${ }^{94}$.

Para comezar, os seus criterios (e os de PM) sobre a orientación necesaria para a mellora pecuaria foron aplicados nos concursos da Cámara agrícola da Coruña e nalgunha outra cidade ata que a finais de 1907 a revista se desvencella da Cámara polas críticas de Calderón ó Ministerio de Fomento (desempeñado por González Besada no goberno Maura) e pola contrariedade ante a inxerencia de elementos oficiais ${ }^{95}$. Ata ese momento Calderón fora corresponsal da mesma en París e en outubro de 1905 delegado seu no congreso mundial de leitería celebrado na capital francesa.

\footnotetext{
92 Bartolomé CALDERón, "La obra de los veterinarios españoles", PM, 167 (1-01-1910) e "La trashumancia y la ciencia veterinaria oficial”, PM, 174 (15-04-1910); Cesáreo SANZ EGAÑA, "Por alusiones", PM, 168 (15-01-1910) e "Para concluir", PM, 178 (15-06-1910).

93 Que tamén tiña presencia en Galicia, Antonio BernÁRdez SoBreIRA, "Gran propiedad y movilización sociopolítica del campesinado. La Asociación General de Ganaderos del Reino en Galicia durante el primer tercio del siglo XX”, Cuadernos de Estudios Gallegos, 113 (2000), páxs. 177-204.

94 Como o titulado "La leche" que aparece na coruñesa Galicia Agraria, 71 (15-01-1930). A referencia a este respecto é Alberte MARTíneZ, O cooperativismo católico no proceso de modernización da agricultura galega, 1900-1943, Pontevedra, Deputación Provincial, 1989.

95 "Una carta de Calderón", VG (4-10-1907).
} 
Outra vía para a difusión das súas teses foi a través das Asembleas agrarias, presentando dende París informes e elaborando boa parte dos seus cuestionarios, co cal moitas das súas teses (libre importación de millo, orientación pecuaria...) foron incorporadas ás conclusións e a través delas e indirectamente a partidos políticos de variado signo ata a guerra civil que fixeron propio o programa de Monforte. No caso das Irmandades e logo do Partido Galeguista con máis claridade aínda posto que námbolos dous casos asumiron integramente as conclusións das Asembleas. Tanto Peña Novo como sobre todo Antón Villar Ponte mencionaron explicitamente a Calderón para respaldar a súa crenza no potencial produtivo de Galicia, a reivindicación do librecambismo, a denuncia dos efectos nocivos do centralismo na economía, etc., aínda que obviamente non era a única autoridade invocada ó respecto posto que por exemplo o antigo lider solidario Rodrigo Sanz tiña teses similares ó respecto da política arancelaria ${ }^{96}$. No que o Partido Galeguista si se distanciou claramente das ideas de Calderón sería no peso reservado ó sector público no futuro estado autonómico.

Malia todo, Calderón caeu no esquecemento ó pouco de morrer e de feito xa nos anos vinte a súa influencia fora retrocedendo. Ademais da súa lonxanía física, sen dúbida algunhas das tendencias da economía española e mundial ían contracorrente dos seus postulados. En particular aplícase isto ó seu liberalismo, posto que en Europa a Gran Guerra e posteriormente a Depresión deron un gran pulo ó intervencionismo económico dos Estados e á regulación cada vez maior dos mercados e das relacións laborais, e a mesma tendencia se aprecia en España entre a fase final da Restauración, a Ditadura de Primo e a Segunda República. Meses antes do seu pasamento proclámase aquéla e Calderón acóllea nos seus derradeiros artigos con cauteloso optimismo. Esperanzado porque tivese chegado de xeito pacífico, temía sen embargo que por unha banda crease expectativas demasiado elevadas que rematasen por sementar o desencanto e pola outra que co novo réxime se acentuase o vicio de agardar demasiado do Estado ${ }^{97}$. As súas ideas eran as de sempre, pero o mundo en cambio seguía a transformarse e en decembro dese ano Bartolomé Calderón abandonaríao definitivamente e entraría nun longo esquecemento que aquí se tentou contrarrestar. O golpe de Estado de 1936 e a conseguinte dictadura anularon as bases das que partía a súa proposta de reforma económica para Galicia (cooperativismo, artellamento da sociedade civil, descentralización...) e consagraron ulteriormente a súa desaparición do debate tanto público como nos medios especializados.

\footnotetext{
${ }_{96}$ Por exemplo no seu artigo "Índice pra unha teoría da nosa valorización económica” en La Zarpa (2601-1923) Villar Ponte invoca “a opinión lumiosa de Bartolomé Calderón” para demostrar que a gandería galega saía prexudicada polo proteccionismo.

97 “La República y la economía”, VG (8-05-1931) e co mesmo título VG (23-05-1931).
} 


\section{BIBLIOGRAFÍA}

Alvarado y Albó, Juan, Epistolario, Villablino, Asociación Xeitu, 2014.

Beramendi González, Justo, De provincia a nación, Vigo, Xerais, 2007.

Bernárdez Sobreira, Antonio, "Gran propiedad y movilización sociopolítica del campesinado. La Asociación General de Ganaderos del Reino en Galicia durante el primer tercio del siglo XX”, Cuadernos de Estudios Gallegos, 113 (2000), páxs. 177-204.

Cabo, Miguel, O agrarismo, Vigo, A Nosa Terra, 1998.

Cabo, Miguel, "Solidaridad Gallega y el desafío al sistema de la Restauración, 1907-1911", Ayer, 64 (2006), páxs. 235-259.

Cabo, Miguel, "Mirando cara ó Norte: a fascinación por Dinamarca na Galiza do primeiro terzo do século XX", Murguía. Revista Galega de Historia, 32 (2015), páxs. 83-92.

Cabo, Miguel e Vázquez Varela, Xosé M., "Las otras guerras de nuestros antepasados. la violencia comunitaria en la Galicia rural contemporánea”, Hispania, 251 (2015), páxs. 781-804.

Conde Gómez, Diego, Canto val unha vaca? Da cuestión agraria á cuestión pecuaria en Galicia, Deputación da Coruña, 2014.

Conde Gómez, Diego, Juan Rof Codina: renovación na veterinaria e gandería galega contemporánea, Vigo, Xerais, 2015.

Cores Trasmonte, Baldomero, "O tren dos tres 'CCC", Anuario Brigantino, 28 (2005), páxs. 239-264.

Durán, José Antonio, Agrarismo y movilización campesina en el país gallego (1875-1912), Madrid, Siglo XXI, 1977.

Fernández Clemente, Eloy, "Bases teóricas de una política económica regeneracionista", en Vicente Salavert Fabiani e Manuel Suárez Cortina (eds.), El Regeneracionismo en España. Política, educación, ciencia y sociedad, Univ. De València, 2007, páxs. 81-124.

Fernández Prieto, Lourenzo, Labregos con ciencia, Vigo, Xerais, 1992.

Fernández Prieto, Lourenzo, Bernárdez, Antonio e Cabo, Miguel, "Valeriano Villanueva y la lógica de la pequeña explotación agraria familiar contemporánea”, en M. Aguilar Villagrán, et al. (eds.), Homenaje a Antonio Cabral Chamorro, Historiador (1953-1997), Trebujena: Centro de Estudios y Documentación, 1998, páxs. 255-274.

Fernández Prieto, Lourenzo e Cabo, Miguel, "Agrarismo y regeneracionismo en la Galicia de comienzos del siglo XX. El discurso del regionalismo agrícola", Agricultura y Sociedad, 86 (1998), páxs. 133-162.

Fernández Sancha, Antonio, Julio Senador: un pensamiento a contracorriente, Valladolid, Junta de Castilla y León, 2001.

Ínsua, Emilio X., A Nosa Terra é Nosa! A xeira das Irmandades da Fala (1916-1931), A Coruña, Baía Edicións, 2016.

Martínez, Alberte, O cooperativismo católico no proceso de modernización da agricultura galega, 1900-1943, Pontevedra, Deputación Provincial, 1989.

Offer, Alver, The First World War: an agrarian Interpretation, Oxford, Clarendon, 1989.

Pinar, Susana, "La introducción de la genética en España durante el primer tercio del siglo XX”, Llull, 22 (1999), páxs. 453-473.

Román Lago, I. e Bernárdez Sobreira, A., Labrando na rebelión: societarismo e populismo agrario en Galiza: 1896-1936, Vigo, A Nosa Terra, 2007.

Román Portas, Mercedes, "Aliadofilia y neutralidad en La Voz de Galicia en los años de la Primera Guerra Mundial”, Historia y Comunicación Social 18 (2013), páxs. 293-303. 
Saurín de la Iglesia Rosa María, Antonio, Francisco y Benigno de la Iglesia: una biografia intelectual, Santiago, Instituto de Estudios Gallegos Padre Sarmiento - CSIC, 2003 (Anejos de Cuadernos de Estudios Gallegos, 31).

Villanueva, Valeriano, Organización del cultivo y de la sociedad agraria en Galicia y en la España atlántica (edición de J. A. Durán), Madrid, Xunta de Galicia e MAPA, 1984. 